IULIIA DOROKHINA ${ }^{1}$

\title{
Public Consultations as a Vital Aspect of Effective Cooperation Between the Government and Civic Organisations in Ukraine
}

Crisis-related phenomena in Ukraine's political and social life highlight the issue of wide public involvement into the process of management decision preparation and making. For a successful resolution, it requires not only the existence of both rights enshrined in the constitution and political institutions formed in a democratic way but also a variety of forms and means by which citizens can influence state authorities. Consequently, the effectiveness of cooperation between the public and state authorities depends on the level of institutionalisation of public social and political life that may support civil society organisations.

Socio-historical practice confirms that the significance of civil society structures increases objectively when the level of public trust in state institutions diminishes. Their involvement in the political process as an alternative to the traditional political institutions facilitates the creation of conditions for civil and political talks, maintenance of social stability and civil peace.

Public consultations are an effective and justified form of public involvement in the state policy making tested in stable democratic countries. According to researchers, the absence of stable practice of public consultations with public organisations in modern Ukraine is the main reason for a low efficiency of state activity. It is worth mentioning that the state administration system inherited by Ukraine from the USSR had no practice of public consultations. As the views advocated and cultivated by the official state ideology were identical, they did not recognise various groups of public interests, and thus their right to be protected during the state decision-making.

The ways of achieving that state are foreseen in complementary fields of activities of state authorities and public associations and their effective

1 Iuliia Dorokhina, PhD, Administrative, Financial and Informational Law Department, Kyiv National University of Trade and Economics. 
cooperation, in other words putting state and governmental institution activity in compliance with new democratic principles and European standards of public administration.

Public consultations as a vital aspect of efficient cooperation between domestic governmental and civil society organisations, in spite of their topicality for modern Ukrainian society, have not been adequately reflected in research contributed by scholars. At the same time, it is worth noting that public consultations as a constituent part of efficient cooperation between the state and the public have not been yet analysed comprehensively and in detail in the studies of Ukrainian authors.

The article is aimed at analysis of public consultations in relation to their influence on improved efficiency of cooperation between state and civil society organisation in the context of international experience.

The formation of a democratic administrative system is one of the most important tasks of modern social transformations. International experience suggests that the establishment of such a system requires new professional knowledge, skills, procedures and institutions. It includes both state institutions and public structures interested in radical social reforms that can be carried out only by strong authorities (with a view to securing wide public support) and the support can be received from public organisations and associations.

To carry out successful transformations, power represented by the government should: have a clear strategy and identified priorities of its execution; be able to determine necessary resources based on detailed analytical materials; foresee consequences and possible risks that may occur during the implementation of a public transformation programme and suggest alternatives; be familiar with transformation management methods. For their part, public organisations should: represent interests of social groups during decision-making related to these groups; cooperate with the state at the stage of state policy making and adoption. Searching for forms of cooperation between state power and public organisations to execute tasks of social development in democratic countries, the forms of direct substantive cooperation of governmental and public organisations related to state policy issues are developed, and public consultations are one of them.

Their consolidation as effective forms of cooperation between state authorities and the public are determined by the fact that the technology of political decision-making in these countries is used taking into account interests of different public groups and it is based on the procedure of public consultations and carried out through standards and procedures adopted in international practice.

Analysis of the current situation in Ukraine indicates the absence of effective public consultations of state authorities with public organisations as one of the reasons for a low efficiency of state activity in general. The 
significance of public discussions in the course of state policymaking in modern Ukraine is increasing due to: the appearance of a great variety of different groups of interests in Ukrainian society; difference in their attitudes to state policy issues; increase in the level of civic self-awareness and citizens' intention to take part in state policy-making.

An essential prerequisite for the enhancement of the impact of public organisations on state policymaking is their increased numbers as well as their improved organisational capability. European and international practice of the involvement of civic organisations in the process of state decision-making is based on the necessity of an unconditional execution and assurance of one of the fundamental human rights - the right to freedom of association and assembly. Article 11 of the European Convention on Human Rights and Fundamental Freedoms reads: "Everyone has the right to freedom of peaceful assembly and to freedom of association with others, including the right to form and to join trade unions for the protection of his interests" ${ }^{2}$. Another document of international importance stipulating European standards concerning a place and role of public organisations was adopted in July 2002 by the participants of an multilateral meeting organised by the Council of Europe in Strasbourg. It is entitled "Fundamental principles on the status of non-governmental organisations in Europe"3.

Thus, at present, the most comprehensive and systematic consolidation of standards concerning civil society development generally recognised by European states is contained in the "Recommendations of the Committee of Ministers of the Council of Europe to the member states on legal status of non-governmental organisations in Europe (2007)". Normative and legal parameters are determined in the document for NGO performance as one of the most important institutions of civil society. They are based on regulations of Article 15 of the Statute of the Council of Europe ${ }^{4}$.

The authors of the document mention that the member states of the Council of Europe shall be governed in accordance with the European standards, which should be taken into account in national legislation development and state policy formation. In addition, it is noted that the Recommendations shall be taken into account during monitoring of obligations taken by the member countries. It is proposed to distribute the Recommendations among the public in general, NGOs to which the text relates directly, parliamentarians, relevant state bodies and educational

2 The Convention for the Protection of Human Rights and Fundamental Freedoms, http://search.liga.kiev.ua/1_doc2.nsf/alldocact2/MU50K02U?OpenDocument (4.06.2017).

3 Fundamental principles on the status of non-governmental organisations in Europe. Adopted by the members of a multilateral meeting organised by the Council of Europe in Strasbourg, 5 July 2002, "Yurydychnyi visnyk Ukrainy" 2002, No. 50.

4 The Statute of the Council of Europe (London, 5th of May 1949), http://www.coe. $\mathrm{int/en/web/conventions/full-list/-/conventions/treaty/001} \mathrm{(8.07.2017).}$ 
institutions in every possible way. Certain paragraphs of the document stipulate the necessity of its use during training of state officials. Peculiarities

Details of public consultations as an efficient tool for cooperation between state bodies and civic organisations in the $\mathrm{EU}$ are stipulated in the Communication of theEuropean Commission entitled "Towardsa reinforced culture of consultation and dialogue - General principles and minimum standards for consultation of interested parties by the Commission". Moreover, it is noted that the aim of consultations is to collect comments and suggestions of interested parties: "Consultation mechanisms form part of the activities of all European Institutions throughout the legislative cycle, from the phase of policy-shaping prior to a Commission proposal to final adoption of a measure by the legislature and its implementation. Depending on the issues at stake, these consultations are aimed at providing opportunities for input in particular from representatives of regional and local authorities, civil society organisations, undertakings and associations of undertakings, individual citizens concerned, academics or technical experts, as well as interested parties in third countries"5.

In another document, namely, a White Paper on European Governance ${ }^{6}$ it is stated that consultations of interested parties can may have additional influence on the accepted legal solution, but they can not change the decision-making process and its final outcome. Only the Council and the Parliament as law-makers shall bear responsibility for the adopted legislatives acts. It is exactly why the European Commission gives an opportunity to interested parties to express their opinion but not to vote ${ }^{7}$.

The consultation process in the EU provides for its institutionalisation. Organisations - intermediaries are chosen to organise the process. The intermediaries in organising consultations for the Commission, the Parliament and the Council are specialised advisory bodies, namely the European Economic and Social Committee (EEESC) and the European Committee of the Regions (CoR). The European Commission gives them an opportunity to play an active role in the process of consultations. It is worth mentioning that in 2001 the European Commission issued Minutes on cooperation of the EESC and the CoR with the aim of consolidating the role of the Committees as "intermediaries" between organised civil society (corresponding to the EESC) and representatives of the regional level (corresponding to

5 Communication of the European Commission. Document for consultation: Development of communication culture and meetings/Proposal for general principles and minimal standards for consultations of interested parties by the Commission-Brussels, 5 June 2002.

6 European Governance. A White Paper, Brussels, 25.7.2001, COM(2001) 428 final.

7 L. Usachenko, Public consultation as constituent part of efficiency of cooperation between domestic state and public structures in the context of international experience, http://www.nbuv.gov.ua/old_jrn/e-journals/tppd/2008-4/R_2/09ulmkmd.pdf (5.06.2017). 
the CoR $)^{8}$. According to Article 300(2) of the Treaty on the Functioning of the European Union EESC "shall consist of representatives of organisations of employers, of the employed, and of other parties representative of civil society, notably in socio-economic, civic, professional and cultural areas". The Committees as advisory bodies are authorised to play a key part in the public consultation process?.

The essential condition of public consultations in the EU is an adequate and equal attitude towards all interested parties. Although the groups of interests for consultations are chosen in accordance with their fields of interest, the measures for taking part in consultations are provided for all interested parties. The consultation process is based on organisations of civil society that play an important role as participants of a wide political dialogue. For the European Commission, "organisations of civil society" shall mean: organisations representing participants of the labour market (trade unions, federations of employers - that is "social partners"); organisations representing social and economic players that are not social partners by definition (consumer organisations); non-governmental organisations uniting people for common problem solving (in the field of the environment or human right protection, charity, educational and sport organisations); community-based organisations (namely, ones established at the level of local communities to solve their problems - they can be youth associations, family and other types of associations used by a public association to take part in local life, religious unions, etc).

European and international experience confirms that there are some principal attitudes determining the efficiency of public consultations: at first, determination of the "audience" to hold public consultations with. Such "audience" should include those interested but not the "public" in general. The "public" shall mean any group of representatives of social organisations or certain citizens in general. Involvement in such a format cannot offer any insights as to how many and what kind of people shall be invited to the discussion to represent public opinion and how to use discussion results. However, groups of interests have a certain number of their representatives in the public environment, and the results of discussion with their participation can be analysed from the perspective of their attitude and suggestions on governmental decisions proposed. Work with the "public" is an abstract thing and it is not a determined activity in social space and time, it has no and cannot have any clear administrative procedures. Therefore, in western countries work is done with groups of interests that can be clearly defined and constructive dialogue can take place. As regards Ukraine, at present there is not enough structured society, so most

8 Communication from the Commission, Towards a reinforced culture of consultation and dialogue - General principles and minimum standards for consultation of interested parties by the Commission, Brussels, 11.12.2002, COM(2002) 704 final, p. 8.

9 Ibidem. 
discussions are held exactly with an undefined audience in the form of a set of predictable speeches before adopting resolutions prepared in advance.

Secondly, what matters is the choice of discussion format. The best result is achieved when public consultations are held not in the form of a set of separate speeches but as a whole activity. In western countries, for instance, topical political issues are brought up for discussion to reveal relevant attitudes of the interested parties and take into account the results of the discussions during state and political decision making and adoption. This way, public consultations are considered as a whole activity where all interested parties have a right to express their opinion rather than preplanned speeches delivered by prepared speakers as is often the case in Ukraine.

Thirdly, the discussion results offer certain decision-making based on analysis of the attitude of all interested parties. Practical experience confirms that the basis of methods for public consultations adopted in the European Union and other countries of developed democracy is stage-bystage decision approval. Without building stages in discussions on decisions it is impossible to achieve the European standards. Analysis of studies held by ICPS in relation to public consultations by the Ukrainian central bodies of executive power (CBEP) lets one determine the difficulties in their adoption as part of management activity practice ${ }^{10}$. The primary challenge found among them is overcoming the adherence of state authorities to conducting public discussions with documents prepared in advance.

On the basis of the reflection and analysis offered here concerning the problem area of this study, the following conclusions can be drawn. At present, Ukraine is required to adopt more vigorously standards and formats of public consultations adopted in the European Union, which are an essential constituent part of cooperation between state bodies and civic organisations that should facilitate better efficiency of cooperation between them in the process of democratising Ukrainian society since true democracy provides for normalised procedures and formats of cooperation between state authorities and civil society.

\section{Bibliography}

Communication of the European Commission. Document for consultation: Development of communication culture and meetings/Proposal for general principles and minimal standards for consultations of interested parties by the Commission, Brussels, 5 June 2002.

Fundamental principles on the status of non-governmental organisations in Europe. Adopted by the members of a multilateral meeting organised by the Coun-

10 Public policy for public organizations. Practical guidelines for works in the field of public policy, V.A. Nikitin., V.T. Nanivska (eds.), Kyiv, International Center for Policy Studies. 
Public Consultations as a Vital Aspect of Effective Cooperation Between the Government. . . RAP 2017 (3)

cil of Europe in Strasbourg, 5 July 2002, "Yurydychnyi visnyk Ukrainy", 2002, no 50.

Public policy for public organisations. Practical guidelines for works in the field of public policy, V.A. Nikitin, V.T. Nanivska (ed.), Kyiv, International Center for Policy Studies.

Usachenko L., Public consultation as constituent part of efficiency of cooperation between domestic state and public structures in the context of international experience, http://www.nbuv.gov.ua/old_jrn/e-journals/tppd/2008-4/R_2/09ulmkmd. $\operatorname{pdf}(5.06 .2017)$.

Abstract

The article discusses the role of public consultations in establishing efficient cooperation between state bodies and civil society organisations. It discusses the experience of public consultations in the countries of the European Union, offers an analysis of the terms and factors of their effective influence on the process of public policymaking as well as ascertains their significance for practice of state administration in modern Ukraine.

Keywords: public consultations, the public, civic organisations, civil society, state authorities, state policy

\section{Konsultacje społeczne jako istotny element skutecznej współpracy pomiędzy władzą rządową a organizacjami pozarządowymi na Ukrainie \\ Streszczenie}

W artykule omówiono rolę konsultacji społecznych w ustanowieniu skutecznej współpracy pomiędzy organami państwa a organizacjami społeczeństwa obywatelskiego. Autorka analizuje doświadczenie konsultacji społecznych w krajach Unii Europejskiej, omawiając warunki i czynniki ich skutecznego wpływu na proces tworzenia polityk publicznych oraz znaczenie dla praktyki administracji państwowej współczesnej Ukrainy.

Słowa kluczowe: konsultacje społeczne, ogół społeczeństwa, organizacje obywatelskie, społeczeństwo obywatelskie, władze państwowe, polityka państwa. 